\title{
The Cult of the Roman Emperor before and after Christianity
}

It has been observed many times that rituals have a tendency to survive in spite of the various changes that may occur in the accompanying mythical explanations. Often, mast of the people practising the great majority of religions are not at all interested in whether there is total agreement about why a ritual is carried out, as long as the how is agreed upon. Phrased as a slogan: Myths perish — rituals endure. (It should be noted that 'myths' to me in this context are primarily tales accompanying and explaining rituals. 'Hoc est corpus meum' (E.g. Luk. XXII, 19) will serve as an example.)

There is certainly no dearth of examples of perishing myths and enduring rituals. It will suffice to remember that the most important Islamic rituals are from the pre-Islamic era, but in Islam they are mythically explained as being founded by Abraham and that their meaning was forgotten, but the acts preserved. That many Christian holidays are celebrated as a result of the syncretism of Christ and another Hellenistic god, Sol, the sun, is generally considered undeniable.

That rituals endure, whereas myths perish is obvious to the historian of religion in the long perspective. In the shorter perspective, on the individual level, things may look quite different. For some reason, an individual may choose to change his religion, and thereby reject one set of myths and even rituals for the benefit of another. Whole nations may undergo this process too, and I will not deny that the changes in mythology may be very significant, even if some of the rituals in these latter cases seem to continue relatively undisturbed.

This paper is concerned with a complete set of rituals and certain connected ideas, namely the Roman emperor-cult, that had survived the change of religion from Roman religion to Christianity. It has often been noted that there are strong ties between Byzantine Christianity and the imperial Byzantine ceremonial (Grabar 1936), but the continuity from the 
non-Christian emperor-cult is rarely stressed.

Numerous problems surround this undertaking; there are several different views of the events that led to the change of religion, and the cult of the emperor has in itself been differently viewed by different researchers. It is therefore necessary for me to make my own views clear from the outset.

To me, the emperor-cult includes the rituals and symbols which surround the Roman emperor and clearly demonstrate that he is more than an ordinary human. It is not ususal to regard this expression of Roman religious feeling with very great interest (Price 1884: 11-22), but in my view, this is a mistake. I believe that the study of the emperor-cult permits a clearer appreciation of the development of Roman religion in the last centuries of its existence.

It is obvious that the rule of the emperor was from its very beginnings something quite extraordinary and suspicious in the eyes of the adherents of the old Roman religion. It is interesting that Octavian, at the same time as he was making this new-fangled invention into an institution, was also carrying on a thorough restoration and revitalization of the ancient Roman religious institutions. Quite possibly it was a message that the new age did not signify the dissolution of the old ways. It is extremely important that the Roman emperor acquired and retained complete control over Roman religious life via the office of the Pontifex Maximus, and that the ancestry and to a certain degree the person of the emperor was divine. Numerous prescriptions and rituals served to demonstrate that the emperor was more than human in the city of Rome itself, and in the provinces this concept was strongly amplified.

There are, in my view, two different sides to the emperor-cult. On the one side there is the ceremonial around the person of the emperor in Rome, on the other side the cult of the emperor which was prevalent in the provinces, in particular in Asia Minor, where divine rulers were almost a commonplace. It is often stressed that this temple-cult of the emperor (to many the 'emperor-cult proper') is a phenomenon chiefly found in Asia Minor, and thus not a Roman one. This understanding is oblivious to the fact that during his 'restoration' of the old Roman religion, Octavian - with the religious title of Augustus ${ }^{1}$ - managed to get his name mentioned in the hymns of the Salian priests, one of the oldest and most venerable of Roman cults.

\footnotetext{
1 Linking him to Mercury, which may be very significant as this god is often understood as a mediator between the divine and the human worlds. This is an ideal role for an emperor - also in Christian times.
} 
The cult of the emperor differs from other cults of the Roman empire in two decisive ways. In the first place, sacrifice is never made to the emperor, but always 'on behalf of' the emperor. Secondly, the depictions of the emperor have an abnormally large significance. In keeping with Hellenistic tradition, the emperor-cult could be joined to the worship of the most important local divinity, in whose temple an imperial statue was then set up. In this context it should be remembered that Caligula tried to make the Jews accept this form of worship connected with the worship of Jahweh in the temple of Jerusalem. It will be remembered that already in 167-165 BCE Antiochus IV Epiphanes prohibited the cult of Jahweh and instituted the cult of Zeus in his stead.

In all other ways, the cult of the emperor was precisely like all other Roman cults in the Hellenistic world. The usual sacrifices, periodical feasts (e.g. the birthday of the deity) were held in the usual manner, and as usual there was in the locality a college of priests made up of the best men of the town or place.

The significance of the picture of the emperor can be illustrated by the fact that all depictions of the emperor were cult-images and therefore sacrosanct. At the foot of the emperor's statue, a person was unpunishable. When a slave was sold, the seller was obliged to inform the prospective buyer about previous escape attempts and whether the slave had ever run to an image of the emperor.

Regarding the court ceremonial and the daily rituals, our information is scarce. How great a role one ascribes to the reforms of Diocletian, or the development under the Christian Byzantine emperors thus becomes very important. The main problem is whether one believes that the very stiff ceremonial, known from descriptions of the Byzantine court are a result of a late Byzantine development or a continuation of ancient Roman practices. In my view, which is based on the studies of Andreas Alföldi, a number of features of the Byzantine ritual are quite close to the ceremonial from at least the second or third centuries.

I shall later present some arguments for this belief, but first I will deal with the continuity from pre-Christian into Christian times which I think is to be found in the position of the emperor in the temple-cult.

It is, as I have mentioned, particularly in Asia Minor that the templecult of the Roman emperor could be seen as a continuation of the local religious customs, but there are signs that Augustus tried to unify the imperial power and local religious customs, both in Egypt ${ }^{2}$ and in the

\footnotetext{
2 I should note that Professor Bergmann, in his opposition mentioned that the
} 
Celtic areas. In Gaul, for example, Augustus seemed to be working toward an identification of himself with the most important pan-Celtic diety, Lug $^{3}$, whose annual festival, luckily for Augustus, fell around the beginning of the month of August (Fishwick 1987: 99-102).

That the emperor-cult did, however, have better foundations, also ideologically in Asia Minor is illustrated by the fact that 'ordinary' Roman generals were worshipped there, even while alive. This was of course according to the ancient custom whereby victorious generals or overlords were worshipped in their loyal city-states. The cult of the emperor breaks away from this tradition in that the emperor is a remote impersonal master instead of a close and well-known one, with personal ties in the different cities. In the longer run, the individual emperors lose their importance in comparison with the more impersonal group of 'augusti' or ' $\sigma \varepsilon \beta \alpha \sigma \tau o$ ' in Greek. The emperor cult is also from the outset a way of integrating the provinces in the Roman realm and can therefore be seen as part of the process of romanization (Ørsted 1985: 15). In this context it can be mentioned that the Roman calendar of Julius Caesar was adopted by the province of Asia Minor and a new era begun on the birthday of Augustus as part of a plan to 'honor the god'. This integrating aspect of the emperor-cult is often stressed when the change to Christianity is discussed, but it can be shown to have been important from the very beginning of the empire.

It has already been mentioned, that the college of priests was made up of local VIP's, who in this way came into contact with the central power. The occasional public cult-festivals were a cause for general joy and amusement and would for a moment bring all of the populace into almost personal contact with the distant government.

According to Simon Price, 77 temples dedicated to emperor-worship have been found in Asia Minor. 21 of these are undatable, and this makes it uncertain whether the building of temples came to an end towards the $3 \mathrm{rd}$ century. The most likely date of seven of the undatable temples would place them in this century, and all in all it would seem more likely that the building of temples continued as before.

With the adoption of Christianity, the building of temples stopped, but in its stead an imperially financed church construction period began on a similar scale. The close connexion between the official sacred architecture of the emperor-cult and the earliest official church architecture has been

evidence for an imperial cult in Egypt is unclear and scarce.

${ }^{3}$ Lug was quite probably also identified with Mercury, who in Gaul, as in many other places has the epithet 'Augustus'. 
discussed (Haussig 1971: 40-43), but few will deny that the earliest legal church buildings were planned and executed under the auspices of the emperor. At the same time, the leaders of the Christian cults were given important posts in the administration, with the consequence that local VIP's were soon found among the leaders of the Christian cult, and Christianity became part of a career in the same fashion as earlier the emperor-cult. It is also important to remember that the first five important emperors, Constantine (with his mother), Theodosius I, Theodosius II, Marcian, Leo I and their wives, were incorporated in the Christian throng of divine beings, in that they all became saints, so that they might be worshipped in their new 'temples' at fixed times of the year, and so that they might be invoked as divine saviors.

Prayers on behalf of the emperor and for his life and health continue with undiminished force in the new religion. It is certain that the exteriors are different, less bloody, possibly more decent and less conducive towards public joy and amusement, but the continuity is easy to see. It can be added that all competing cults can now be exterminated gradually with military force on the initiative of the emperor.

This presupposes a view of Christianity as the special, personal religion of the emperor, a kind of continuation of the emperor-cult. This view will not be seen as the whole truth by either today's Christians or the Christians of the time. And rightly so, when seen from the Christian perspective. But if things are seen in a larger perspective, I think it is a reasonable point of view. As a comparison, I would like to bring up the emperor Elagabal, who reigned from 218-222. Apparently he tried to fuse the cult of the emperor with the cult of the sun as an alternative to the traditional Roman religion (Halsberghe 1972). His methods were much more heavy-handed than Constantine's, and he failed miserably, but I cannot see any basic difference between the fundamental projects of the two emperors. Elagabal tried to introduce the worship of the Syrian god of the sun, of the same name, but with the Roman epithet 'sol invictus'. Elagabal, the emperor, was the personification of his god and therefore his private quarters were the most sacred place in the empire. In monotheistic consequence thereof, he moved all the most sacred objects of Rome to his bedchamber, including the superior Vestal Virgin, whom he married in an act of obvious sacrilege. Besides he gave important posts to the cultleaders of his religion, before the old Roman aristocracy did away with him.

In our context, it is noteworthy that Constantine also worshipped the unconquered sun, whom he seems to have identified with Christ. He 
was depicted as Sol, and he tried to move some of the holiest objects of Rome to his own new Rome, Constantinople. He placed the leaders of his new religion in the highest posts, but he was much more careful and gradual than Elagabal, and he avoided long stays in the city of Rome. Furthermore, he left the Vestal Virgins alone, and it is noteworthy that precisely this cult is the last non-Christian cult to have functioned in Rome - an obvious sign of the deep respect this cult in particular enjoyed. Maturity and wisdom separate Constantine from Elagabal, not the goal they were after. This goal seems to have been to make the emperorcult the religion of the Roman empire through one or another sun-related cult. The Christian imperial power preserved the sun-relation, which can be seen most clearly from the fact that one of the emperor's attributes was the nimbus of the sun-god. The most likely inspiration for the idea that empire and sun-cult were connected is probably the Ahura Mazdah-cult of the Persian royal power.

It is also obvious that Constantine and his successors, by virtue of their office as Pontifices Maximi, were counting on the leading role in the affairs of the new religion. All the early ecumenical Christian councils convened on the initiative of the emperor. At these councils, unity was the main purpose and the main idea - a unity of opinion and faith, which seems to be quite alien and quite new to Christianity, and which at any rate was never achieved.

The opposition which faced Constantine from the Church almost from the outset only goes to show, in my opinion, that he was not involved in any conspiracy with the Christian leaders, even if his plans did turn out to be successful without any major difficulties. The continuation of the imperial cult in the Christian Roman state can also be observed from the fact that the pictures of the emperor retained their sanctity and continued to be the object of awe and worship. The usual portentous omens which are found in large numbers in pre-Christian writers such as Suetonius concerning the emperial statues are still seen, now as an expression of divine will. Furthermore, the opponents of Julian the Philosopher complained that Julian let his image be set up among the non-Christian gods, so that people, when dutifully offering reverence to the imperial image, also uwittingly offered homage to the gods. By this time it was no longer questioned that the imperial image should be honored.

The relationship between the emperor and his image can also be used to explain the relationship between the Father and the Son of the Trinity, one of the more important differences between 'Catholic' and 'Arian' Christians. Athanasius used the following example in an attack on the 
Arians in c. 360 : "... The image could say to a man, who wished to see the king after [having seen] the image: 'The king and I are one; for I am in him and he is in me!" (Athanasios, Oratio III contra Arianos, 5). The special official powers of the bishop of Rome, the Pope, were conferred upon him by the emperor - first under Gratian II - and when the emperor was reigning over the Church it was therefore not really caesaropapism. The papacy is rather a continuation of certain imperial powers in the Western half of the empire - it could be described as papacaesarism - and according to this view, Byzantine Christianity was a relatively undisturbed continuation of the reinforced imperial cult of Constantine, not an aberration, where the emperors assumed more and more power over the Church. This last view can sometimes be found, but I do not believe it can be substantiated. ${ }^{4}$

This brings us to the court ceremonial known from Byzantium. The most important feature is that the emperor literally is the image of God, and therefore is made to appear as little as possible as a human being. Our best source of information is from a book by the emperor Constantine Porphyrogennetos from the 940s, Liber de Caeremoniis, and from an ambassador of the German Emperor, Liutprandt of Cremona, of 968 . The latter wrote two relevant works, the Antapodosis and the Relatio de legatione Constantinopolitana.

The ceremonial underscores the immobility and unapproachability of the emperor. Liutprand mentions a number of mechanical implements, among these some gilt lions that roared and a throne on an elevator, lifting the emperor over the crowd while he sat motionless as a statue. The visitors had to perform the proskynesis, throwing themselves prostrate on the floor, touching it with their foreheads, but this was a matter of course, for it had been the rule since the third century, at least. Alfoldi cites a multitude of earlier examples, dating back to Caesar himself (Alföldi 1970: 46-65).

It is with this ceremonial that parallels have been drawn from the Byzantine-Christian ritual and the Byzantine emperor-cult. The emperor is treated very much like an icon, or rather, the other way round. The whole shape and structure of the Christian basilica is reminiscent of the official imperial halls. Here it must again be stressed that it is possible that the Byzantine imperial ritual with immense conservatism had retained the shape of imperial ceremonial from pre-Christian times. In the Handbook

\footnotetext{
4 In this connection it should be remembered that the Gothic kings of Toulouse in 418-507 considered themselves to be the natural heads of the church as an obvious continuation of ordinary Roman custom (Wolfram 1988).
} 
of Ceremonies by Constantine Porphyrogennetos there are a large number of Latin titles and ceremonial concepts, but written, naturally, with Greek letters and probably incomprehensible as words to the Greek court of the 10th century - Greek, that is, at least since the days of Constantine.

This linguistic evidence is, to me, argument enough, but more can be adduced. In the study of Nordic religion, the handbook of Constantine Porphyrogennetos is known for a remarkable description of the 'so-called Gothic games'. It seems that these games were performed by Greek actors, who among other things had to sing a song which is recorded in the book and contains a lot of incomprehensible words that might be Gothic or at least Germanic. Sometimes this ritual is considered as an influence from Scandinavian mercenaries, 'væringer', but this cannot be true. Rather, the ritual preserves the memory of Gothic presence at the court in the middle of the fourth century.

At that time, the court ceremonial was obviously open to foreign influences, but it is remarkable that this ceremony, which was some 600 years old at the time of Porphyrogennetos, is still mentioned with a distancing 'so called'. In the conservative court-ceremonial this completely grecized ritual was still regarded, I believe, as a 600-year-old renewal.

It is possible to claim that the pre-Christian court ceremonial of the emperor-cult had an important consequence for the shape of the Byzantine church-ritual. In the Latin-speaking West, the development was different, probably because of the failing imperial control over the area.

Regarding the imperial control over the church, it is instructive to contemplate briefly the careers of Julian the Philosopher (361-363) and Justinian I (527-565), because both tried to exert their rightful powers over the religious affairs according to a grand scheme. Julian had taken over the view of the Christians that the non-Christian religions could be regarded as a kind of system, paganism, and he tried to organise these religions after the Christian pattern. He did not persecute the Christians, but he did take their special privileges away from them, and he bothered them in various ways with arguments from the New Testament which he knew through and through. That the removal of Christians from public service caused an uproar clearly shows how much Christianity had become a career even at the time of Julian. His measures seem to a great degree aimed at stopping this practice, but he was, as he himself claimed, less bloodthirsty than his Christian predecessor Constantius, who sought to promote Christian unity with violence. The Christian reply to Julian was the complaint that this apostate would deny them even their martyrs.

The most Christian emperor Justinian has not been given the best 
reports by Christian historians, who have complained about his imperial interference in church matters. But Justinian had the ability and the interest to try to create unity in the Christian church, in order to establish civil peace and safe streets, convincingly uniting the government and the state - the idea of Elagabal and Constantine! As I have already mentioned, such unity seems quite alien to Christianity, and it has never been achieved. It was at the time of Justinian that the last lethal blow was struck against the non-Christian religions, symbolised in the closing of the Athenean schools in 529. As mentioned, it is possible to see the victory of Christianity as an attempt by the imperial power at introducing a single emperor-cult, fused with a sun-cult, into the Roman empire at the exclusion of all previous religious systerns. It is possible that the monotheistic world-view of Christianity made this cult particularly apt for this purpose. It is also true that it all looks quite different at the individual level. For instance, neither Constantine nor Constantius were really Christian, at least not until they were sure of being near death. Julian, who was Christian, experienced a kind of conversion before he decided that the old pagan cults were more praiseworthy than what he called the religion of the Galilees. One of the more famous tales of conversion in the other direction, that of Saint Augustine, is from the $420 \mathrm{~s}$, and it is apparent from his 'Confessions' that intellectuals could not at this time take Christianity seriously. The writings, particularly the Gospels, appeared to be too primitive.

In our ritual context we can conclude that the earliest official Christianity obviously represents a continuation of the Roman emperor-cult in several ways, at least in the shape it took in the 2 nd and $3 \mathrm{rd}$ centuries. In the West, the rituals which endured were placed in such a new and different ideological framework that the connection with the emperor here becomes almost invisible - until one remembers that Catholic Christianity is in the West still headed by a man with the imperial title of Pontifex Maximus.

I promised, finally, that the study of the emperor-cult could provide an insight into the religious development of the Roman empire in the period toward the adoption of Christianity. I will only hint that it must weigh heavily, that more than one emperor seems to have wanted to place all the religions and cults under the emperor-cult, with the use of force if necessary. Monarchy and monotheism seem to be closely connected, and it cannot be sufficiently stressed that the non-Christian religions were strong enough to make it necessary to conduct a war of extermination against them with military force. It is often claimed that the non-Christian cults 
were in a state of utter dissolution, as a result of tough philosophical criticism by intellectuals, but it is forgotten, I think, that this criticism had been leveled against the non-Christian religions for many centuries. It should also be remembered that many non-Christian cults were lively enough to be absorbed and continue in Christianity in another guise. The rituals endure, even while their mythological basis is perishing.

\section{References cited}

Alföldi, Andreas

1970 Die monarchische Repräsentation im römischen Kaiserreiche. Darmstadt: Wissenschaftliche Buchgesellschaft.

Fishwick, Duncan

1987 The Empirial Cult in the Latin West. Leiden: Brill.

Grabar, André

1936 L'empereur dans l'art byzantine. Paris: Les Belles Lettres.

Halsberghe, Gaston

1972 The Cult of Sol Invictus. Leiden: Brill.

Haussig, H. W.

1971 A History of Byzantine Civilization. London: Thames \& Hudson.

$\emptyset$ rsted, Peter

1985 Roman Emperial Economy and Romanisation. Copenhagen: Museum Tusculanum Press.

Price, S. R. F。

1984 Rituals and Power. The Roman Imperial Cult in Asia Minor. Cambridge: Cambridge University Press.

Wolfram, Herwig

1988 History of the Goths. Berkely: University of California Press. 